\title{
Hiding Shame in Science and Scholarship
}

\section{Scheff T*}

Department of Sociology, University of California Santa Barbara, USA

*Corresponding author: Thomas Scheff, Department of Sociology, University of California Santa Barbara, USA, E mail: xscheff@gmail.com

\section{Mini Review}

Volume 3 Issue 2

Received Date: December 15, 2017

Published Date: February 08, 2018

\section{Abstract}

Modern societies tend to ignore emotion, especially the emotion of shame. But for that reason, shame especially may become important to understand. Beginning with Norbert Elias and Helen B. Lewis, there is a literature on shame that might help see its' influence, especially how hiding shame may generate anger and violence. There seem to be many recent systematic empirical studies of shame that use other terms, such as rejection, exclusion, loss of social status, social suffering, search for recognition, honor/dishonor, vengeance/ revenge etc. This practice may be hiding the crucial importance of shame as a cause of violence and many other problems.

From his study of five hundred years of European etiquette and advice manuals, the sociologist Norbert Elias (1939; 1978) proposed that shame and its close kin (embarrassment and humiliation) have been gradually replacing physical punishment as a way of upholding cultural conventions. But at the same time that shame has become more dominant in modern societies, it is less and less mentioned.

Elias's thesis is that there is a difference between shame that is felt, the basis of morality, and shame that is hidden not only from others but even from self. The hiding of shame seems to occur not only in the public but also equally in the world and science and scholarship. Shame is frequently studied in social/behavioral, political and medical science, and history, but under different names so that the term shame is almost completely hidden. Perhaps shame is taboo, not only in the public at large, but also in serious studies of human behavior.

There are many studies in anthropology of "cultures of honor": how insults to honor lead to humiliation and revenge. Most of these studies however, assume that this sequence causes violence only in traditional societies, where shame is out in the open. It is not considered to occur in modern societies. Although the word honor has gone out of style, the emotion of shame has not. It seems to be socially and biologically based, so that it is probably a historical and cross cultural.

The taboo on shame has many weakening effects on knowledge, because it cordons off into separate groups what ought to be a single field, reinforcing the existing taboo. For example, it hides studies that support's Gilligan's (1997) conjecture on hidden shame as a cause of violence, such as rejection, status attainment, loss of social status, social suffering, search for recognition, honor/dishonor, vengeance/ revenge, and so on. It also slows down the process of replicating studies 


\section{Psychology \& Psychological Research International Journal}

that support it, and testing a broader hypothesis extending to causes of both violence and silence. If the shameviolence/silence hypothesis is even partly true, it carries a crucial message for our civilization.

Keywords: Hiding Shame; Hypothesis; Emotions; Argument; Suffering

\section{Hiding Shame}

How can shame become invisible? Modern audiences cannot accept this idea, since they conflate emotion and feeling. However, most people will agree that at times a person's anger can be obvious to others, yet the angry person completely unaware of it. A similar argument can be made about fear: since boys, especially, are taught to equate fear with cowardice, they learn to automatically suppress fear to the point that they don't feel it. It may be that recklessness, particularly, arises from this process. Similarly, perhaps a person can be in a bodily state of shame without feeling ashamed.

Elias interpreted invisibility in terms of taboo: in modernization shame becomes a topic that is not to be talked about, just as sex was such a topic in the $19^{\text {th }}$ century. As sex and especially the f-word were taboo then, so the s-word has become taboo now. The psychologist Gershen Kaufman is one of several writers who have argued that shame is taboo in our society: American society is a shame-based culture, but ...shame remains hidden. Since there is shame about shame, it remains under taboo. The taboo on shame is so strict. That we behave as if shame does not exist [1-5].

The taboo is not on all uses of the word shame, since there are speakable usages, such as "What a shame" or the jokey "Shame on you." What is taboo is the central meaning of shame, the feeling of being excluded and perhaps worthless for that reason. The phrase "What a shame" does not refer to a specific feeling, since "What a pity" means exactly the same thing. Just as the f-word was once completely taboo before the 1960's, the s-word, when used to mean the emotion of shame, is still taboo.

Shame and its siblings are much less discussed than other emotions, not only by the public, but also researchers. How could that be? There have been many studies of shame, but most of them use what Elias called circumlocutions. An illustrative example is found in a recent study of doctor-patient relationships by Leape, et al (2012) [6]. Instead of referring to how the doctor may shame a patient, the title uses the phrase "disrespectful behavior toward patients." The article makes no reference to shame. Although the reader will understand what is meant, the phrase cuts the authors and the readers off from an understanding of shame dynamics that are available in the literature on shame and its siblings.

Studies of the facial expression of emotion, a huge field, were based on the foundational descriptions of basic emotions by Silvan Tomkins. But for many years until quite recently, these studies did not include shame, even though Tomkins gave more attention to it than any other emotion, all of one of the four volumes [7].

Another example is stigma. There are thousands of studies in the social, behavioral and medical sciences of this topic. The idea is that police arrest or illness diagnosis may carry with it an unintended consequence: the shaming of the recipient, to self and/or his/her social network. These studies virtually never use the term shame in the title, and in most cases, even in the body of the study. This case illustrates the taboo strongly, since shame is the actual dictionary meaning of stigma.

Goffman's Stigma (1968) clearly equated stigma with shame (pp. 13, 14, 25, 108). But by 1980, when articles on stigma started appearing, the term shame had disappeared. This absence is particularly noticeable in an attempt to conceptualize stigma (Link and Phelan 2001). Although they quote Goffman's book at some length, there is no mention of his use of shame [8].

Another example: more than twenty thousand studies using self-esteem scales. They all make the same error of using a multivariate scale, one cognitive, the other emotional, that involves the pride/shame axis that cancel each other out [9].

In addition to Elias, another early discovery of the taboo on shame was made by Helen Lewis (1971), a research and clinical psychologist. She used the Gottschalk (1969) technique to locate emotion episodes in the transcriptions, and then analyzed the reactions of both client and therapist to each episode. The Gottschalk method concerns words and phrases that are commonly 


\section{Psychology \& Psychological Research International Journal}

understood to indicate emotions, such as "being pissed off" as a way of referring to anger, or "feeling rejected" to shame $[10,11]$.

Lewis's analysis of the results led to two surprises. First, shame episodes were by far the most frequent, outnumbering all the other emotions combined. Secondly, unlike the other episodes, such as anger, the shame episodes were not commented on. Neither therapist nor client seemed to notice them.

In the book, she referred to the seemingly unnoticed shame as unacknowledged, since she couldn't tell whether the therapists and clients were unaware of the emotions, or whether they were aware but not mentioning them. Since Lewis was a practicing psychoanalyst as well as a researcher, she later questioned her own clients when they used words that indicated shame. She found them to be unaware of the shame that their wording implied.

In the 1971 book, in connection with the sequences that occurred after the client's shame episodes, Lewis made two further discoveries. The most frequent sequence was what seemed to be varying degrees of withdrawal by the client. Lewis called this a sequence from shame to depression. The client would begin to speak less and more slowly with less clarity. There was, however, also another response, a sequence from shame to anger, sometimes at the therapist. The anger reaction was less frequent than withdrawal.

As indicated, shame episodes never led into discussion of the episode by client and/or therapist. For example, if something the therapist had said embarrassed the client, he or she might have responded with "That remark you just made me feel ashamed," or even the more indirect "You hurt my feelings." Such a statement might have then led the discussion toward working through the client's shame, a therapeutic sequence. Such a sequence did not occur in any of the 150 sessions.

\section{Hiding Shame}

Lewis proposed that shame is mostly hidden both from others and from self. She found that shame goes unacknowledged in two different ways. The first way she called "overt, undifferentiated shame" (OU). The client is in pain, but it is referred to indirectly, at best. As Gottschalk has shown, there are hundreds of words and phrases in English that can be used to refer to shame without naming it. For example, one can say "I fear rejection," or "This is an awkward moment for me," and so on. Many of these cognates have been listed by Retzinger (1995) [12].

OU shame is usually marked not only by pain, but often by confusion and bodily reactions: blushing, sweating, and/or rapid heartbeat. One may be at a loss for words, with fluster or disorganization of thought or behavior, as in states of embarrassment. Many of the common terms for painful feelings appear to refer to this type of shame, or combinations with anger: feeling hurt, peculiar, shy, bashful, awkward, funny, bothered, or miserable; in adolescent vernacular, being freaked, bummed, or weirded out. The phrases "I feel like a fool," or "a perfect idiot" are prototypic.

Stigma, Social Pain and Suffering, Rejection, etc.

Stigma has become the center of a huge body of research, but has not been defined in a way that is accepted by most researchers [13]. In the enormous number of stigma studies, very few even mention shame, much less define stigma as a type of shame.

In his frequently cited book on stigma, Goffman (1963) was a bold exception: he used the word continuously throughout. Here are four of his many sentences that contain the s-word. (I have bolded the shame terms. However, in the last quote, the word shameful was already bolded in the text). Notice that in the second quote, three shame terms occur in a single sentence:

Shame becomes a central possibility, arising from the individual's perception of one of his own attributes as being a defiling thing to possess, and one he can readily see himself as not possessing. (P. 7, first chapter.)

Most important of all, the very notion of shameful differences assumes a similarity in regard to crucial beliefs, those regarding identity. (P. 13)

(The stigmatized person's) identification with (other) offenders like himself (e.g. mentally ill) holds him to what repels him, transforming repulsion into shame, and then transforming ashamedness itself into something of which he is ashamed. (P.108)

Once the dynamics of shameful differentness are seen as a general feature of social life, one can go on to look at the relation of their study to the study of neighboring matters associated with the term "deviance"...(P. 140, last chapter). 


\section{Psychology \& Psychological Research International Journal}

Goffman does not define stigma as shame directly (as most dictionaries do), but his frequent and emphatic usage in these and other passages imply it.

Goffman's frequent usage suggests that stigma is a certain kind of shame, the kind caused by labeling. Many of the later books and articles on stigma cite Goffman's book, but avoid the shame word. One edited book (Heatherton et al, 2000) cites it 9 times, but without noting his insistent use of the S-word. The word itself is used 5 times in this book, but never alone; as frequently happens when it occurs, the taboo is softened because it is mixed in with other, less offensive or more abstract emotion names, such as guilt, anxiety, etc [14].

The idea of "the looking-glass self" (Cooley, 1902, 184186) is cited in three of the Heatherton et al book's chapters. Indeed, it is used in the title of one of the chapters: "The Looking-glass Self Revisited." But none of the citations mention that Cooley proposed that the process of seeing one's self in the eyes of others always ends in pride or shame. The widely quoted review of the stigma literature by Major and O'Brien (2005) cites Goffman's book three times but doesn't cite Cooley nor mention shame at all $[15,16]$.

The idea of "social suffering and pain" is much broader than that caused by labeling alone: it involves all pain caused by any kind of rejection $[17,18]$. Like the edited books on stigma, these two volumes hardly mention shame, the emotion that is caused by real or imagined rejection $[19,20]$. Shame does not appear in the index of either volume. It is used 9 times in the MacDonald and Jensen-Campbell book, but only in passing or in the company of other unrelated emotions.

Many of the rejection studies show that shame may be a cause of anger and violence, as in the case of school shooting.

The term rejection is used in shame study titles far more often than any other. This list contains only a small number of the existing studies: Downey, et al. (2000); Gaertner \& Iuzzini (2005; Gaertner (2008); Stenseng (2014); Twenge and Campbell, (2003); Wesselmann, et al. (2010); Williams et al (2005); Williams, et al. (2015). The most frequent contributor to studies of rejection has been Mark Leary with five items: Leary, Editor (2001); Leary, et al. (2003). Leary, et al. (2006); Leary \& Jongman-Sereno (2014); Leary (2015) [21-28].
The last field to be considered is what is called "the desire for status" (Anderson, et al. 2015); Cheng and Tracey (Eds.) 2014. It is left for last because unlike the huge number of fields named above that seem to have no idea that their topic is intimately connected with shame, this field shows slight signs of recognition. The word shame occurs five times in the Anderson essay itself in the course of telling the findings of five of the articles that are cited, because these articles use the s-word. This is a thin relationship to the idea of shame, since there is no citing of the shame literature itself [29-35].

Ignoring the whole shame literature surely doesn't help the attempts to understand stigma, social pain and suffering, status striving, rejection/violence, etc. Unfortunately, this practice does help the public continue to ignore the shame in their lives and in their societies. It would appear that social/behavioral and neurological scientists are just as loath to use the S-word as the general public, if not more so. What is to be done: study and discuss shame directly instead of hiding it behind various covers. This undertaking would require making some fundamental definitions since the vernacular words for shame and its opposite, pride, are confused and confusing.

From my experience with these problems, it seems to me that the emotion language and ideas in modern societies are not just tropes, but a special type of trope. An ordinary trope is a widespread belief held so firmly that it goes without saying (Gibbs 2015). The vast structure of beliefs in a society is made up of interlocking tropes, but some of them are strongly defended against change of any kind. Kepler's discovery that the planets revolve the sun rather than the earth probably wasn't a huge shock to the public; their daily life didn't depend on it. But the idea that some emotions are positive and others negative seems to be a crucial trope, one that will be defended as if peoples' lives depended on it, and will continue to face virtually immovable resistance to change.

\section{Conclusion}

A taboo on shame in modern societies is suggested by the large number of studies of shame that use alternative terms. The ratio is probably much higher than the five to one that we found in our systematic study. The idea that shame is taboo in modern societies points to the necessity of bringing it out in the open. Perhaps it can be done first in scholarship, then with the public. It appears that many of the worse features of modern societies, such as 


\section{Psychology \& Psychological Research International Journal}

withdrawal, violence and unnecessary conflict, may be caused, in part, by the hiding of shame. Other areas that might be better understood: the punitive element in legal systems, especially in imprisonment, hung negotiations and mediations, and individual and mass prejudice in social class, ethnic/racial and gender relationships. Perhaps it may be possible to bring shame out of the closet at least as far as been done with sex.

\section{References}

1. Gilligan James (1997) Violence - reflections on a national epidemic. New York: Vintage Books, pp: 306.

2. Lacey David (2009) The Role of Humiliation in Collective Political Violence. Sydney: University of Sydney Press.

3. Websdale Neil (2010) Familicidal Hearts: The Emotional Style of 211 Killers. Oxford: Oxford University Press.

4. Thomas Scheff (2011) A Theory of Multiple Killing. Aggression and Violent Behavior 16(6): 453-460.

5. Kaufman, Gershon (1989) The Psychology of Shame. New York: Springer.

6. Leape LL, Shore MF, Dienstag JL, Mayer RJ, EdgmanLevitan S, et al. (2012) the Nature and Causes of Disrespectful Behavior by Physicians. Academic Medicine 87(7): 845-852.

7. Tomkins, Silvan (1963) Affect, Imagery, Consciousness. Volume II. New York: Springer.

8. Goffman, Erving (1983) Stigma. Englewood Cliffs: New Jersey.

9. Scheff T, David Fearon Jr (2004) Social and Emotional Components in Self-Esteem. Journal of the Theory of Social Behavior 34(1): 73-90.

10. Gottschalk, Louis A, Winget C, Gleser G (1969) Manual of Instruction for Using the Gottschalk-Gleser Content Analysis Scales: Anxiety, hostility and social alienation-personal disorganization, Berkeley: UC Press 12(3): 290-292.

11. Gottschalk, Louis A (1995) Content analysis of verbal behavior: new findings and clinical applications. Hillsdale, NJ: Lawrence Erlbaum Associates, pp: 240.
12. Retzinger, Suzanne (1995) Identifying Shame and Anger in Discourse. American Behavioral Science. 38(8): 1104-1113.

13. Thomas Scheff (2014) Defining Stigma. International J. of Social Psychiatry 7: 222-225.

14. Hetherton Ted, Kleck R, Hebl M, Jull J (2000) The Social Psychology of Stigma. New York: Guilford, pp: 450.

15. Cooley, Charles H (1902) Human Nature and the Social Order. New York: Schocken

16. Major Brenda, O'Brien LT (2005) The social psychology of stigma. Annual Review of Psychology 56: 393-421.

17. Kleinman, Arthur V Das, M Lock (1997) Social Suffering. Berkeley: University of California Press. pp: 425.

18. MacDonald Geoff, Jensen-Campbell L (2011) Social Pain: Neuropsychological and Health Implications of Loss and Exclusion. Washington DC: American Psychological Association.

19. Scheff $T$ (1987) Case Study of an Interminable Quarrel, in The Role of Shame in Symptom Formation, Helen B. Lewis (Editor). Patterson, NJ: LEA.

20. Thomas Scheff (2015) Twenty-five years of rejection research. In Williams K, Nida S (Eds.), Handbook of ostracism, social exclusion, and rejection. New York: Psychology Press.

21. Downey G, Feldman S, Ayduk O (2000) Rejection sensitivity and male violence in romantic relationships. Personal Relationships 7(1): 45-61.

22. Stenseng F, Belsky J, Skalicka V, Wichstrøm L (2014) Preschool Social Exclusion, Aggression, and Cooperation A Longitudinal Evaluation of the Needto-Belong and the Social-Reconnection Hypotheses. Pers Soc Psychol Bull 40(12): 1637-1647.

23. Twenge JM, Campbell WK (2003) Isn't it fun to get the respect that we're going to deserve? Narcissism, social rejection, and aggression. Pers Soc Psychol Bull 29(2): 261-272.

24. Leary MR (2001) Interpersonal rejection. New York: Oxford University Press. 


\section{Psychology \& Psychological Research International Journal}

25. Leary MR, Kowalski RM, Smith L, Phillips S (2003) Teasing, rejection, and violence: Case studies of the school shootings. Aggressive Behavior 29(3): 202214.

26. Leary MR, Twenge JM, Quinlivan E (2006) Interpersonal rejection as a determinant of anger and aggression. Pers Soc Psychol Rev 10(2): 111-132.

27. Leary MR, Jongman-Sereno KP (2014) when rejection kills: The central role of low relational value in school violence. International Journal of Developmental Science 8(1-2): 25-27.

28. Anderson C, Hildreth JA, Howland L (2015) Is the Desire for Status a Fundamental Human Motive? A Review of the Empirical Literature. Psychol Bull 141(3): 574-601.

29. Cheng J, Tracey J (2014) The psychology of social status, New York: Springer, pp: 159-178.

30. Anastasio PA, Rose KC (2014) Beyond Deserving More Psychological Entitlement Also Predicts
Negative Attitudes Toward Personally Relevant OutGroups. Social Psicológica and Personalista Sciences 5(5): 593-600.

31. Ayduk Ö, Gyurak A, Luerssen A (2008) Individual differences in the rejection-aggression link in the hot sauce paradigm: The case of rejection sensitivity. J Exp Soc Psychol 44(3): 775-782.

32. Crosskey LB, Curry JF, Leary MR (2015) Role transgressions, shame, and guilt among clergy. Pastoral Psychology 64(6): 783-801.

33. Elias, Norbert (1939) Über den Prozess der Zivilisation. Reprinted in 1978 as The Civilizing Process. London: Blackwell.

34. Bruce G Link, Jo C Phelan (2001) Conceptualizing Stigma. Annual Review of Sociology 27: 363-385.

35. Schoel C, Eck J, Greifeneder R (2014) A matter of vertical position: Consequences of ostracism differ for those above versus below its perpetrators. Social Psychological and Personality Science 5(2): 149-157. 